\title{
USAHA MIKRO KECIL DAN MENENGAH (UMKM) DALAM MENINGKATKAN KESEJAHTERAAN MASYARAKAT
}

\author{
Wika Undari ${ }^{1)}$ Anggia Sari Lubis ${ }^{2)}$ \\ 1,2) Program Studi Manajemen Universitas Muslim Nusantara Al-Wasliyah \\ anggiasarilubis@gmail.com
}

\begin{abstract}
Abstrak
Tujuan penelitian adalah untuk mengetahui perkembangan dan peranan Usaha Mikro Kecil dan Menengah (UMKM) di Kecamatan Perbaungan Kabupaten Serdang Bedagai terhadap kesejahteraan ekonomi masyarakat. Metode penelitian ini adalah metode kualitatif dengan teknik pengumpulan data berdasarkan observasi dan wawancara dengan informan 6 orang. Teknis analisis data penelitian ini adalah analisis deskriptif. Hasil penelitian ini menunjukkan bahwa Perkembangan Usaha Mikro Kecil dan Menengah (UMKM) di Kecamatan Perbaungan Kabupaten Serdang Bedagai cukup berkembang, karena dari sisi kualitas para pelaku UMKM pada umumnya masih mampu bertahan dan menjalankan usaha produksi dan dagangannya. Peran Usaha Mikro Kecil dan Menengah (UMKM) dapat meningkatkan kesejahteraan masyarakat, karena keberadaan UMKM mampu memenuhi kebutuhan ekonomi keluarga, mampu mengurangi pengangguran dan mampu memenuhi kebutuhan masyarakat yang memproduksi berbagai jenis makanan untuk dijual di kios pelaku UMKM.
\end{abstract}

Kata kunci: peranan, usaha mikro kecil dan menengah UMKM, kesejahteraan masyarakat

\begin{abstract}
The research aims to determine the development and role of Micro, Small and Medium Enterprises (UMKM) in Perbaungan Subdistrict, Serdang Bedagai on the economic prosperity of the community. The research is conducted by using qualitative method with data collection techniques based on observation and interviews with 6 informants and descriptive analysis as the technical analysis. The result indicates that the development of Micro, Small and Medium Enterprises (UMKM) in Perbaungan Subdistrict, Serdang Bedagai is quite developed, because in terms of quality, UMKM are generally able to survive and run their production and trade businesses. The role of Micro, Small and Medium Enterprises (UMKM) can improve the prosperity of the community, because the existence of UMKM is able to meet the economic needs of the family, able to reduce unemployment and be able to meet the needs of the people who produce various types of food for sale at UMKM actors' stand.
\end{abstract}

Keywords: role of UMKM and community welfare

\section{PENDAHULUAN}

\subsection{Latar Belakang Masalah}

Kegiatan ekonomi adalah suatu usaha untuk meningkatkan daya dan taraf hidup masyarakat, karena dengan semakin meningkatnya pertumbuhan ekonomi maka kebutuhan masyarakat dapat terpenuhi. Untuk memenuhi kebutuhan masyarakat maka dibutuhkan lapangan kerja yang mampu menyerap setiap angkatan yang ada. Indonesia sebagai negara yang penuh dengan kekayaan alam, tetapi belum mampu untuk memaksimalkan potensi yang ada.

Usaha yang dilakukan untuk memenuhi kebutuhan hidup diantaranya melakukan Usaha Mikro Kecil Menengah. Keberadaan dan keberlangsungan hidup Usaha Mikro Kecil dan Menengah (UMKM) ikut dipengaruhi juga oleh kedua faktor internal seperti motif ekonomi dan eksternal yaitu lingkungan dan habitat ekonomi yang menjadi tempat hidup seseorang atau suatu komunitas dalam melakukan kehidupan ekonominya. 
Usaha Mikro Kecil dan Menengah (UMKM) yang merupakan bagian terbesar dalam perekonomian nasional, merupakan indikator tingkat partisipasi masyarakat dalam berbagai sektor kegiatan ekonomi. Usaha Mikro Kecil dan Menengah (UMKM) selama ini terbukti dapat di andalkan sebagai katup pengaman dimasa krisis, melalui mekanisme penciptaan Usaha Mikro Kecil dan Menengah (UMKM) berarti memperkokoh bisnis perekonomian masyarakat. Hal ini akan membantu mempercepat proses pemulihan perekonomian nasional, dan sekaligus sumber dukungan nyata terhadap pemerintah daerah dalam melaksanakan otonomi pemerintah.

Perkembangan Usaha Mikro Kecil dan Menengah (UMKM) merupakan proses yang sangat baik untuk membawa suatu bangsa menuju kemakmuran. Perkembangan Usaha Mikro Kecil dan Menengah (UMKM) dapat memperluas lapangan kerja, dan memanfaatkan potensi sumber daya alam maupun sumber daya manusia sehingga akan meningkatkan pertumbuhan ekonomi suatu negara.

Berdasarkan data Dinas

Kementerian Koperasi Indonesia bahwa perkembangan UMKM di Indonesia menunjukkan bahwa jumlah UMKM sebanyak 50 juta unit UMKM di seluruh Indonesia, sedangkan di wilayah Sumatera Utara sebanyak 2.857.124 unit sedangkan untuk wilayah Kabupaten Serdang Bedagai sebanyak 23.591 unit dan untuk wilayah Kecamatan Perbaungan 120 unit.

Berdasarkan data di atas dapat diketahui bahwa data BPS Sumatera Utara, dari tahun 2016-2018 jumlah UMKM di Sumatera Utara terus terjadi peningkatan jumlah UMKM yang terdaftar dan terverifikasi pada Dinas Koprasi dan UMKM dan hal ini cenderung meningkat setiap tahunnya, dan pada umumnya perkembangan ini berada di daerah perkotaan.

Berdasarkan data nasional pada tahun 2018 sekitar 3,79 juta pelaku UMKM di Indonesia telah memanfaatkan teknologi digital atau bisnis e-commerce sementara perkembangan UMKM di Sumatera Utara secara umum terjadi peningkatan, namun dalam wilayah Kabupaten Serdang Bedagai khususnya Kecamatan Perbaungan selama tiga tahun terakhir terjadi penurunan jumlah UMKM.

Usaha UMKM yang ada di Kecamatan Perbaungan khususnya UMKM dalam pembinaan Dinas Perdagangan dan Perindustrian Kabupaten Serdang Bedagai yang ada di Pasar Bengkel adalah aneka jajanan berupa dodol, keripik ubi, rengginang, mie yeye, opak, keripik pedas, keripik ubi rambat/ubi jalar, dan berbagai macam jajanan lain, sebahagian khas dari daerah setempat dan sebahagian lain adalah jajanan umum, namun tetap buatan asli pengrajin setempat.

Dua tahun terakhir ini terjadi penurunan penjualan dan pendapatan pelaku UMKM sehingga mempengaruhi terhadap pendapatan masyarakat, sebab menurut data kantor camat terdapat kurang lebih 99 kios yang berjejer di sekitar sepanjang jalan, dimana pada awalnya kios jajanan ini berjumlah kurang lebih 150 kios namun akhir 2018 tercatat hanya 120, karena terdapat 30 kios yang sudah tutup. Hal ini disebabkan karena dua faktor yang pertama berkurangnya pembeli setelah beroperasinya jalan tol Medan -Tebing Tinggi sehingga bus dan kenderaan yang singgah dan membeli berkurang, sedangkan faktor kedua adalah kurangnya modal yang dimiliki oleh pelaku UMKM.

Oleh karena itu peneliti ingin melihat lebih dekat sejauhmana peran UMKM dalam meningkatkan kesejahteraan hidup masyarakat saat ini. Karena untuk meningkatkan peran Usaha Mikro Kecil dan Menengah (UMKM) dalam Kesejahteraan maasyarakat perlu dilakukan berbagai upaya mengatasi permasalahan kesejahteraan masyarakat yang ada, khususnya di Kecamatan Perbaungan Kabupaten Serdang Bedagai. Untuk meningkatkan pendapatan masyarakat serta membantu program pemerintah dalam usaha meningkatkan perekonomian daerah 
dan nasional.

\subsection{Tujuan Penelitian}

Berdasarkan uraian latar belakang maka tujuan penelitian ini adalah untuk:

1. Untuk mengetahui perkembangan Usaha Mikro Kecil dan Menengah (UMKM) di Kecamatan Perbaungan Kabupaten Serdang Bedagai

2. Untuk mengetahui peran Usaha Mikro Kecil dan Menengah (UMKM) dalam meningkatkan kesejahteraan masyarakat

3. Untuk mengetahui kendala yang dihadapi Usaha Mikro Kecil dan Menengah (UMKM) dalam meningkatkan kesejahteraan masyarakat

\section{METODE}

\subsection{Desain Penelitian}

Metode analisa data yang digunakan penulis dalam menganalisa masalah yang ada dengan analisis data deskriptif kualitatif. Menurut Arikunto (2013: 10) metode penelitian deskriptif kualitatif adalah sebuah metode yang digunakan peneliti untuk menemukan pengetahuan atau teori terhadap penelitian pada satu waktu tertentu. Metode yang diterapkan dalam penelitian ini adalah metode deskriptif kualitatif. metode ini digunakan untuk mengetahui gambaran dan pengaruh Peran UMKM dalam Meningkatkan Kesejahteraan masyarakat.

Penelitian deskriptif kualitatif yaitu penelitian yang lebih menekankan pada aspek pemahaman yang mendalam terhadap suatu permasalahan, bersifat deskriptif dan cenderung menggunakan analisis yang lebih mengutamakan proses dan makna. Penelitian ini dimulai dengan mengumpulkan data, menghitung data dengan cara mempelajari, mengamati dan menganalisis dokumen dokumen yang berhubungan dengan objek penelitian dan diakhiri dengan kesimpulan.

\subsection{Sumber Data}

Sumber data yang digunakan adalah:

1. Data primer, melalui kegiatan wawancara dengan subjek penelitian dan dengan observasi atau pengamatan langsung di lapangan yang diperoleh melalui wawancara dengan pelaku Usaha Mikro Kecil dan Menengah (UMKM). Informan penelitian ini adalah 1 orang Dinas Perindustrian, Camat Perbaungan 1 orang, 3 orang pelaku UMKM dan 1 orang pekerja UMKM seluruhnya 6 orang.

2. Data Sekunder, informasi yang didapatkan dari sumber data sekunder yaitu dari bahan pustaka, literatur, penelitian terdahulu, buku, laporanlaporan kegiatan yang berasa dari pelaku Usaha Mikro Kecil dan Menengah (UMKM).

\subsection{Teknik Pengumpulan Data}

Selanjunya jika dilihat dari segi cara atau teknik pengumpulan data, maka teknik pengumpulan data dapat dilakukan dengan cara sebagai berikut:

1. Triangulasi

Dalam melakukan triangulasi, peneliti mengumpulkan data yang sekaligus menguji kredibilitas data, yaitu mengecek kredibilitas data dengan berbagai teknik pengumpulan data dan berbagai sumber data.

2. Interview ( Wawancara )

Wawancara adalah percakapan dengan maksud tertentu yang dilakukan oleh dua pihak, yaitu pewawancara yang mengajukan pertanyaan dan narasumber yang memberikan jawaban atas pertanyaan itu (Moleong, 2012:156).

3. Dokumentasi

Teknik dokumentasi merupakan catatan peristiwa yang sudah berlalu. Dokumen bisa berbentuk tulisan, gambar, atau karya-karya monumental dari seseorang. Dokumen yang berbentuk tulisan misalnya catatan harian, sejarah kehidupan, peraturan, kebijakan. Dokumen yang berbentuk gambar, misalnya foto, gambar hidup, sketsa dan lain sebagainya. Dokumen yang berbentuk karya, misalnya karya seni yang dapat berupa gambar, patung, film dan lain sebagainya ( Mudrajat, 2010: 
240).

\section{HASIL DAN PEMBAHASAN}

Secara umum, tujuan atau sasaran yang ingin dicapai adalah terwujudnya Usaha Mikro Kecil dan Menengah (UMKM) yang tangguh dan mandiri yang memiliki daya saing tinggi dan berperan utama dalam produksi dan distribusi kebutuhan pokok, bahan baku, serta dalam permodalan untuk menghadapi persaingan bebas. Mempengaruhi stabilitas nasional, ekonomi dan politik yang imbasnya berdampak pada kegiatan-kegiatan usaha besar yang semakin terpuruk, sementara Usaha Mikro Kecil dan Menengah (UMKM) serta koperasi relatif masih dapat mempertahankan kegiatan usahanya.

Usaha Mikro Kecil dan Menengah (UMKM) yang merupakan bagian terbesar dalam perekonomian nasional, merupakan indikator tingkat partisipasi masyarakat dalam berbagai sektor kegiatan ekonomi. Usaha Mikro Kecil dan Menengah (UMKM) selama ini terbukti dapat di andalkan sebagai katup pengaman dimasa krisis, melalui mekanisme penciptaan Usaha Mikro Kecil dan Menengah (UMKM) berarti memperkokoh bisnis perekonomian masyarakat. Kesejahteraan yaitu suatu tahap dimana terpenuhinya kebutuhan hidup seseorang sehingga orang tersebut merasa cukup dan tidak mempunyai ke khawatiran minimal dalam memenuhi kebutuhan hidupnya seperti makan, minum, kesehatan, dan pendidikan untuk memenuhi semua itu sudah sewajarnya dalam hal ini UMKM bisa mendongkrak dan menjadi motor kesejahteraan masyarakat menengah kebawah.

Sebagaimana diketahui bahwa peran penting Usaha Mikro menurut Departemen Koperasi tentang Undang-Undang Perkoperasian Tahun 2008 menyebutkan:

a. Sebagai pemeran utama dalam kegiatan ekonomi

b. Penyedia lapangan pekerjaan terbesar

c. Pemain penting dalam pembangunan perekonomian lokal dan pemberdayaan masyarakat

d. Pencipta pasar baru dan sumber ekonomi, serta

e. Kontribusinya terhadap neraca pembayaran

Tidak dapat dipungkiri bahwa Usaha Kecil dan Menengah memegang peranan penting dalam memajukan perekonomian suatu negara. Demikian halnya dengan keberadaan UMKM yang ada di Kecamatan Perbaungan para pelaku Usaha Mikro Kecil dan Menengah (UMKM) dengan berbagai jenis industri kecil dan berbagai jenis dagangan yang dilakukan oleh masyarakat khususnya yang ada di Desa Perbaungan Bengkel dapat mendongkrak dan mempengaruhi terhadap pembangunan ekonomi masyarakat di Desa Perbaungan Bengkel.

Salah satu dari manfaat dan peran Usaha Mikro Kecil dan Menengah (UMKM) di Desa Perbaungan Bengkel Kecamatan Perbauhngan adalah:

1. Meningkatkan ekonomi masyarakat, diantaranya adalah:

a. Meningkatkan penghasilan ekonomi keluarga

b. Menambah penghasilan bagi karyawan atau pekerja

c. Menambah penghasilan bagi masyarakat yang memproduksi berbagai jenis makanan yang dapat dijual kepada pedagang

2. Mengurangi pengangguran

Melalui keberadaan Usaha Mikro Kecil dan Menengah (UMKM) ternyata dapat mengurangi pengangguran di kalangan masyarakat yang selama ini tidak memiliki pekerjaan sebagai karyawan di beberapa toko atau tempat jualan.

3. Melahirkan pelaku usaha lainnya Dengan adanya kios dagangan para pelaku Usaha Mikro Kecil dan Menengah (UMKM), maka muncul berbagai usaha keliling dari masyarakat setempat seperti jual sate kerang keliling, jual gorengan keliling, jual mie keliling dan sebagainya. Melalui berbagai jenis usaha yang dilakoni oleh Usaha Mikro Kecil dan Menengah 
(UMKM) yang ada di Desa Perbaungan Bengkel Kecamatan Perbaungan dapat meningkatkan kesejahteraan ekonomi masyarakat, karena dengan usaha tersebut baik pelaku usaha, pekerja dan masyarakat yang memproduksi berbagai jenis industri kecil dan makanan dapat memenuhi berbagai kebutuhan seperti:

a. Kebutuhan ekonomi keluarga baik primer maupun skunder

b. Kebutuhan pendidikan anak-anak

c. Terjaminnya kesehatan masyarakat melalui penghasilan yang diperoleh

Dari kertiga indikator tersebut menjadi prasyarat terpenuhinya kebutuhan ekonomi masyarakat berdasarkan penghasilan dan pendapatan per hari maupun per bulan melalui pekerjaannya. Sebagaimana hasil pembahasan dan analisa yang dilakukan maka dapat diambil kesimpulan sementara bahwa keberadaan Usaha Mikro Kecil dan Menengah (UMKM) yang ada di Desa Perbaungan Bengkel

Kecamatan Perbaungan berperan meningkatkan ekonomi masyarakat, namun dalam dua tahun terakhir ini terjadi penurunan penghasilan karena berbagai faktor, faktor yang paling mempengaruhi adalah berkurangnya bus dan mobil pribadi yang singgah dan membeli hasil produksi Usaha Mikro Kecil dan Menengah (UMKM) disebabkan karena banyaknya bus dan mobil pribadi yang masuk via tol dari Medan ke Tebing Tinggi atau sebaliknya. Hal ini tentunya menjadi bahan pemikiran dan pertimbangan bagi pemerintah setempat dalam upaya ,mengatasi permasalahan para pelaku Usaha Mikro Kecil dan Menengah (UMKM) yang ada di Kecamatan Perbaungan.

\section{KESIMPULAN}

1) Perkembangan Usaha Mikro Kecil dan Menengah (UMKM) di Kecamatan Perbaungan Kabupaten Serdang Bedagai terjadi perkembangan yang cukup pesat, karena dari sisi kualitas para pelaku UMKM pada umumnya masih mampu bertahan dan menjalankan usaha produksi dan dagangannya.

2) Peran Usaha Mikro Kecil dan Menengah (UMKM) dapat meningkatkan kesejahteraan masyarakat, karena keberadaan UMKM mampu memenuhi kebutuhan ekonomi keluarga, mampu mengurangi pengangguran dan mampu memenuhhi kebutuhan masyarakat yang memproduksi berbagai jenis makanan untuk dijual di kios pelaku UMKM.

3) Kendala yang dihadapi Usaha Mikro Kecil dan Menengah (UMKM) di Desa Perbaungan Pasar Bengkel Kecamatan Perbaungan dalam meningkatkan kesejahteraan masyarakat adalah terjadinya penurunan omzet penjualan karena berkurangnya pembeli yang diakibatkan oleh berkurangnya bus dan mobil pribadi yang singgah karena dengan dibukanya jalan tol banyak bus dan mobil pribadi lewat jalan tol. Akibatnya ada beberapa pelaku UMKM terpaksa tutup.

\section{DAFTAR PUSTAKA}

Ade Muhamad, A, B, (2015), Peranan Usaha Kecil Menengah (UKM) Dalam Meningkatkan Kesejahteraan Masyarakat, Institut Agama Islam Negeri (IAIN) Syekh Nurjati. Cirebon Andersen, (2010), Kebijakan Pemerintah Dalam Pengembangan UMKM, Jakarta: Kemenkop.

Arikunto, S. (2012). Prosedur Penelitian: Suatu Pendekatan Praktek. Jakarta: Rineka Cipta

Arief Rahmana, (2016), "Usaha Kecil dan Menengah (UKM) Informasi Terdepan tentang Usaha Kecil Menengah" dalam Sudaryanto dkk, Strategi Pemberdayaan UMKM Menghadapi Pasar Bebas ASEAN, Pusat Kebijakan Ekonomi Makro BKF, 08 Desember 2014

Arikunto, Suharsimi, (2014), Manajemen Penelitian. Rineka Cipta: Jakarta. 
Badan Pusat Statistik (BPS) Sumatera Utara. (2015-2017). Perkembangan Usaha Mikro Kecil dan Menengah. Badan Statistik Sumatera Utara. Medan

Badan Pusat Statistik (BPS) Kabupaten Serdang Bedagai. (2018). Statistik Kesejahteraan Rakyat Kabupaten Serdang Bedagai. Badan Pusat Statistik (BPS) Kabupaten Serdang Bedagai. Serdang Bedagai

Keputusan Menteri Keuangan No 316/KMK.016/1994 tanggal 27 Juni 1994.

Kuncoro, Mudrajad. (2010). Metode Riset Untuk Bisnisdan Ekonomi. Jakarta: Erlangga.

Mardikanto, Totok dan Poerwoko Soebiato, (2019), Pemberdayaan Masyarakat Dalam Perspekrtif Kebijakan Publik, Bandung: Alfabeta

Moeloeng, Lexy, (2012), Metode Penelitian Kualitatif, Jakarta: Bumi Aksara

Mudrajat, (2010), Penelitian Kualitatif, Bumi Aksara, Jakarta

Nitisusatro, Mulyadi, (2013), Perlaku Konsumen dalam Perspektif Kewirausahaan, Bandung: Alfabeta.

Pandji Anoraga, (2013), Usaha Sektor Riil, Jakarta : Offest

Republik Indonesia, Undang-Undang Nomor 20 Tahun 2008 tentang Usaha Mikro, Kecil dan Menengah, Jakarta: Sekretariat Negara. (2008). Asas dan Tujuan Usaha Mikro, Kecil dan Menengah (UMKM) Menurut Pasal 2 dan 3 Undang-undang No. 20 Tahun 2008 tentang UMKM

Rahman, (2017), Pengambangan Sumber Daya Manusia, Jakarta : Bumi Aksara.

Setyosari, P. (2012). Metode Penelitian Pendidikandan Pengembangan. Jakarta:Kencana.

Sudaryono. (2017). Metodologi Penelitian. Raja Grafindo Persada. Depok

Sukirno Sadono. (2011). Mikro Ekonomi Teori Pengantar. Raja Grafindo Persada. Jakarta

Sugiyono. (2013). Metode Penelitian
Kuantitatif dan Kualitatif R \& D. Bandung: Alfabeta

Sudaryanto dkk, (2014), Strategi Pemberdayaan UMKM Menghadapi Pasar Bebas ASEAN, Jurnal Pusat Kebijakan Ekonomi Makro.

Soejodono, A. (2014). Ekonomi Sekala Kecil/Menengah dan Koprasi. Jakarta ,Ghalia Indonesia.

Suhardjono, (2014), Manajemen Perkreditan Usaha Kecil dan Menengah, Yogyakarta: UPP. AMPYKPN.

Suseno H.G. (2011). Reposisi Usaha Kecil dan Menengah Dalam Perekonomian Nasional. Yogyakarta: Universitas Sanata Dharma

Tambunan, S, (2012), Pemberdayaan UKM di Indonesia, Banfung: Tarsito.

Tambunan, Tulus, (2012), Usaha Mikro Kecil dan Menengah di Indonesia, IsuIsu Penting, Jakarta: LP3ES.

Tohar, M, (2011), Pengembangan UMKM, Jakarta: Bumi Aksara.

Todaro, (2012), UMKM Sebagai Pengembangan Ekonomi Masyarakat, Jakarta: Bina Ilmu.

Undang-Undang Republik Indonesia No.20 Tahun 2008 tentang UMKM. Pasal 1

Manusia. Yogyakarta: AndiOffset.

Grensing-Pophal, Lin. (2008). Human Resource Book. Jakarta: Prenada.

Hariandja, Marihot Tua Effendi. (2002). Manajemen Sumber Daya

Manusia. Cetakan pertama. Jakarta: Gramedia Widia Sarana.

Hasibuan, Malayu SP. (2007). Manajemen Sumber Daya Manusia. Jakarta: Bumi Aksara. Ivancevich, John, Robert

Konopaske, Michael T Matteson. 006. Perilaku Organisasi. Jakarta : Penerbit Erlangga

Kotter, JP, J.L Heskett. (2000). Corporate Culture And Performance. New York: Free Press

Kountur, Ronny. (2007). MetodePenelitian Untuk Penelitian Skripsi dan Tesis. Jakarta : Penerbit PPM

Mangkunegara. (2000). Sumber Daya 
Manusia Perusahaan. Bandung: Penerbit Rosdakarya.

Martoyo, Susilo. (2007). Manajemen Sumber Daya Manusia. Jakarta: BPFE

Mathis, Robert, John H Jackson. (2006). Manajemen Sumber Daya Manusia. Salemba Empat: Jakarta

Moeheriono. (2009). Pengukuran Kinerja Berbasis Kompetensi. Bogor: Ghalia Indonesia

Noe, Raymond A. ( 2002) . Employee Training \& Development. New York : Mc Graw Hill

Prasetyo, Miftahuljannah. (2007). Metode Penelitian Kuantitatif. Jakarta Rajawali Press

Ranupandojo, Hedjrachman dan Suad rta: Grahallmu
Husnan. (2002). Manajemen Personalia. Yogyakarta: Edisi 4 Penerbit BPFE

Rivai, Veithzal. (2004). Manajemen Sumber Daya Manusia Untuk Perusahaan. Jakarta: Raja Grafindo.

Robbins, Stephen P. (2003). Perilaku Organisasi. Jakarta: Penerbit Indeks Sekaran, Uma. (2006). Research Methods For Bussiness. Jakarta: Salemba Empat Saydam, Gouzali. (1996). Manajemen Sumber Daya Manusia. Jakarta: PT. Toko Gunung Agung.

Sofyandi, Herman. (2008).

Manajemen Sumber Daya Manusia . Yogyaka 